\title{
Powieść, biografia i ethos historii w pismach Narcyzy Żmichowskiej
}

DOI: http://dx.doi.org/10.12775/LC.2017.036

\begin{abstract}
Streszczenie: Artykuł mówi o poszukiwaniach nowej formuły powieści, jakie Narcyza Żmichowska podjęła w trzech wypowiedziach metatekstowych: w komentarzu do utworu Książka pamiątek, edycja z roku 1861; w dodatku do niedokończonego dzieła Czy to powieść?, noszącym tytuł Kontur ogólny; oraz w notatce pisanej do Wandy Grabowskiej w połowie lat 60. (dwa ostatnie teksty przytaczamy z edycji Boya z roku 1929). Analizując opozycję powieści i biografii, autorka skłania się ku formie biograficznej, rozumiejąc ją jako narrację, która odwołuje się zarazem do doświadczeń podmiotu piszącego, jak również do wydarzeń ogólniejszych, stanowiących przeżycie pokoleniowe ludzi urodzonych ok. roku 1820. Żmichowska szuka formy, która pogodziłaby tak z pozoru sprzeczne cele, jak odejście od obowiązujących konwencji narracyjnych, dokumentaryzm, zaufanie do przekazów rodzinnych, historii domowych, wrażliwość etyczną i perspektywę kobiecą. Impuls źródłowy dla tych poszukiwań stanowiło doświadczenie więzienne pisarki i dalsze wypadki dziejowe z udziałem Polaków, które uświadomily jej, że powieść (powieść biograficzna) nie może uchylać się zarówno od odpowiedzi na pytanie o kondycję moralną człowieka, stającego przed wyzwaniami historii, jak i od prób wzmocnienia więzi społecznych, które od końca XVIII wieku ulegały rozluźnieniu i osłabieniu.
\end{abstract}

Słowa kluczowe: powieść, biografia, wiek XIX, twórczość kobieca

\section{Novel, biography and history ethos in the works of Narcyza Żmichowska}

Abstract: The article describes the search that Żmichowska has undertaken to find the new formula of a novel in her three metatext speeches: her comment to the Book of souvenirs (Ksiażka pamiatek), 1861 edition, in the addendum to the uncompleted work Is this a novel? (Czy to powieść?) entitled The

\footnotetext{
* Profesor w Instytucie Badań Literackich PAN, kierownik Pracowni Literatury Drugiej Połowy XIX wieku, członek-korespondent Polskiej Akademii Nauk, prezes Towarzystwa Literackiego im. Adama Mickiewicza. Zajmuje się literaturą XIX i XX wieku, ze szczególnym uwzględnieniem twórczości kobiet. E-mail: grazyna-borkowska@wp.pl.
} 
prevailing Contour (Kontur ogólny), as well as in the note written to Wanda Grabowska in the mid-sixties (the source for quotes of the two texts mentioned at the end comes from Boy's edition of 1929). While analyzing the opposition between a novel and a biography, the author seems to be in favour of the latter as a narration that can be shared by the writer as well as those who experienced the moments of history common for the generation of people born around the year 1820. Żmichowska is seeking a literary tool capable of reconciling seemingly contrary aims such as abandoning the prevailing narrative conventions, documentarism, the trust in a family oral tradition, home-born histories and the female perspective. The source of inspiration for this search came from the writer's prison experience and those moments in history that were particularly significant to the Polish perspective. The events she has witnessed and in which She has participated made her aware of the specific role of a biographical novel. She believed that it cannot strive from answering moral questions dealing with the condition of a mankind facing challenges of a specific time in history and making effort to strengthen social bonds that have been weakened since the end of the XVIII century.

Key words: novel, biography, XIX century, women's literature

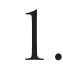

N

arcyza Żmichowska - Gabriella nie mogła dokończyć Książki pamiątek z bardzo istotnego powodu, który wyłożyła anonimowej (lecz nietrudnej do identyfikacji) ${ }^{2}$ interlokutorce $\mathrm{w}$ dopisanym po latach komentarzu do powieści³

[...] pierwej muszę wiedzieć, czy dobrze rozumiesz, jaka zachodzi między utworem wyobraźni a rzeczywistością, między powieścią a biografią - różnica.

- Ta najpewniej, że powieść od biografii piękniejsza.

- Niekoniecznie, o piękności talent stanowi. Jedni piszą daleko piękniej, niż żyć umieją; inni znowu żyją daleko piękniej, niżby to najsławniejszy autor opisać potrafil. Nie, nie, piękności za cechową różnicę między powieścią a biografią nie godzi się uznawać, ale jest pewne stanowcze rozgrodzenie, które je od gór alpejskich łańcuchem przedziela. Powieść ma sens jawny i wybitny; biografia ma sens ukryty i najczęściej niezrozumiały. W powieści zdarzenia ze zdarzeń

\footnotetext{
1 N. Żmichowska, Książka pamiątek [rodz. I-XII], „Przegląd Naukowy” 1847, t. 1-3; 1848, t. 2; rozdziały XIII i XIV: Dalszy ciag „Ksią̇̇ki pamiątek” N. Żmichowskiej znaleziony w papierach autorki, „Bluszcz” 1885, nr 27-30; edycja powieści (po włączeniu odnalezionego fragmentu): eadem, Pisma Narcyzy Żmichowskiej (Gabryelli) z życiorysem autorki skreślonym przez dra Piotra Chmielowskiego, t. 2-3, oprac. P. Chmielowski, Warszawa 1885.

2 Rozmówczynią Gabrielli może być Wanda Grabowska. To ona pomagała w przygotowaniu Pism Żmichowskiej do wydania w oficynie Jana Jaworskiego; ślady tej współpracy znajdziemy w listach Żmichowskiej do przyjaciółki: N. Żmichowska, Listy, t. V: Narcyssa i Wanda. Listy Narcyzy Żmichowskiej do Wandy Grabowskiej (Żeleńskiej), wyd. B. Winklowa i H. Żytkowicz, Warszawa 2007; listy według edycji Boya z roku 1930: N. Żmichowska, Narcyssa i Wanda: listy Narcyzy Żmichowskiej do Wandy Grabowskiej (Żeleńskiej), wyd. i wstęp T. Żeleński (Boy), Warszawa 1930.

3 Komentarzem nazywam kilkustronicowy aneks, zamykający powieść Książka pamiątek. Komentarza tego nie zawierał pierwodruk powieści opublikowany w „Przeglądzie Naukowym”; aneks został dopisany prawdopodobnie w czasie przygotowywania tekstów Żmichowskiej do wydania zbiorowego, a więc przed rokiem 1861, razem z kilkoma zdaniami usprawiedliwiającymi przerwanie powieści. Tych kilka zdań (akapit) edytorzy lokowali tuż pod częścią fabularną powieści, natomiast komentarz tworzył wyodrębnioną, dodatkową i dodatkowo oznaczoną, np. „gwiazdkami”, część utworu. Historia powstania komentarza jest częściowo paralelna wobec historii powstania Wstępnego obrazka z Poganki, którego nie było w pierwodruku powieści, a który pojawił się w wydaniu Jaworskiego.
} 
płyną, charaktery pod grozą recenzji muszą być utrzymane i konsekwentnie przeprowadzone; wszystko, co do głównego wątku nie należy, co do jedności działania nie pomaga, co zasadniczej myśli i dramatycznego efektu nie podnosi, wszystko to - jak nieużyteczne strzępki - obcinać trzeba, gdyż powieść jest przede wszystkim całością, jest dziełem skończonym - niech jak chce, w analizę psychologiczną się wdziera, zawsze od wypadku jej wątek rozsnuty, zawsze musi być określona tym, „co się stało”. Życie zaś do pewnego stopnia nie określa się, nawet bym powiedziała, „stać się” nie może nigdy; życia sens i ład na tym polega, „co się staje” ciągle, co się rozwija i unieśmiertelnia. Artyzmem powieści jest zręczne nawiązanie szczegółów, artyzmem życia - ogólność władz duchowych zbogacona. Prawda powieści dowodzi się faktami, prawda życia urobieniem osobistości naszej. Autor bierze pewne dane moralne i z nich rysuje arabesk odpowiedni: cnoty, występki, namiętności, uczucia wszelkie dla autora są materiałem przygód i dziejów - przygody i dzieje są dla człowieka żyjącego materiałem tylko uczuć, namiętności, występków lub cnoty. Powieść rozwiązuje się ostatecznie dolą lub niedolą, szczęściem lub nieszczęściem; biografia dolę lub niedolę, szczęście i nieszczęście przetwarza w niedowidzianą, niedosłyszaną, niedocieczoną, wewnętrzną historię zbawienia - powieść z kilku nieskończoności atomów skończone dzieło tworzy, biografia przez wszelkie dzieła skończone ku nieskończoności idzie ${ }^{4}$.

Ten rewelacyjny fragment poddawano rozmaitym interpretacjom; w zarysowanej paraleli interesował badaczy przede wszystkim status nowego sposobu opowiadania, wywiedziony z wyczuwalnej rezerwy wobec narracji tradycyjnej. Owszem, stematyzowana po raz pierwszy w Książce pamiątek, a potem dopełniana przy różnych okazjach, powieściowa linia poszukiwań Żmichowskiej jest niesłychanie interesująca; czyni z autorki prekursorkę nowych rozwiązań narracyjnych, bliskich - jak się wydaje - temu, co później zostanie nazwane literaturą dokumentu osobistego, biografiami kolaboratywnymi, a może również literaturą faktu lub tą przestrzenią, którą Berent ują jako bios historii. By jednak lepiej rozumieć opozycję biografii i powieści, a także by trafniej rozpoznawać kierunek myślenia Żmichowskiej, nigdzie przecież w pełni nieobjaśniony, nieskomentowany - niezbędny jest również namysł nad biografią, nad jej dwuznaczną semantyką, wyrażającą zarówno prawdę życia, jak i prawdę sztuki, nad dramatycznym zawęźleniem różnych porządków, które, gdy spojrzeć szerzej, mają również swoje tradycje gatunkowe, swoje konwencje narracyjne i swoją historię.

\section{2.}

Tradycje polskiej biografistyki, choć tworzonej często po łacinie, sięgają późnego średniowiecza i renesansu (Janko z Czarnkowa, Jan Długosz, hagiografie, żywoty świętych, i dalej - Marcin Czechowic, Erazm Otwinowski, Marcin Wolski, Piotr Skarga, Stanisław Orzechowski), a refleksje nad samą biografistyką - czasów oświecenia. W Zbiorze potrzebniejszych wiadomości porządkiem alfabetu ułożonych przez Ignacego Krasickiego i innych autorów nie ma hasła biografia, jest natomiast hasło: biograf, czyli „autor, który życia znamienitych ludzi opisał. Tacy byli w starożytności: u Greków Plutarchus, u Rzymian - Cornelius Nepos, w Polszcze - Starowolski”. W podobnym duchu pisał Euzebiusz Słowacki, nazy-

\footnotetext{
4 N. Żmichowska, Pisma, t. 3, s. 125-126.

5 I. Krasicki, Zbiór potrzebniejszych wiadomości porządkiem alfabetu ułożonych, t. 1, Warszawa 1781, s. 161.
} 
wając biografię obrazem „wielkiego jakiego człowieka” i przypominając dzieła Plutarcha, Ksenofonta, Diogenesa Laertiosa, Tacyta i Swetoniusza ${ }^{6}$.

Sam Krasicki był autorem trzech tomów biografii, tłumaczonych z Plutarcha lub pisanych na wzór antycznego autora - Życia zacnych mężów z Plutarcha (dwa tomy) oraz Życia zacnych mężów na wzór Plutarcha. Metoda prezentacji bohaterów Krasickiego powtarzała zasadę paraleli, wymyśloną w starożytności przez ojca biografiki, Plutarcha: po przedstawieniu pary bohaterów następowało porównanie obu postaci. Krasicki postępuje tak, niezależnie od tego, czy dokonuje przekładu dzieł starożytnych, czy oddaje się pracy własnej wyobraźni, budując paralelę nie z gotowego tekstu, ale z jego fragmentów (tekst dotyczący pary: Epaminondas-Scypion Młodszy zaginąl). W oświeceniu po ten gatunek sięgali też m.in. Filip Neriusz Golański, Franciszek Ksawery Dmochowski, który Życia uczonych ludzi publikował w „Nowym Pamiętniku Warszawskim” w latach 1801-1803 (biografie Stanisława Konarskiego, Krasickiego, Karola Wyrwicza, Teodora Wagi, Teodora Ostrowskiego, Ignacego Zaborowskiego, Mikołaja Wolskiego, Józefa Rogalińskiego, Grzegorza Piramowicza i Józefa Szymanowskiego, wydanie osobne w Pismach rozmaitych, 1826, cz. 2).

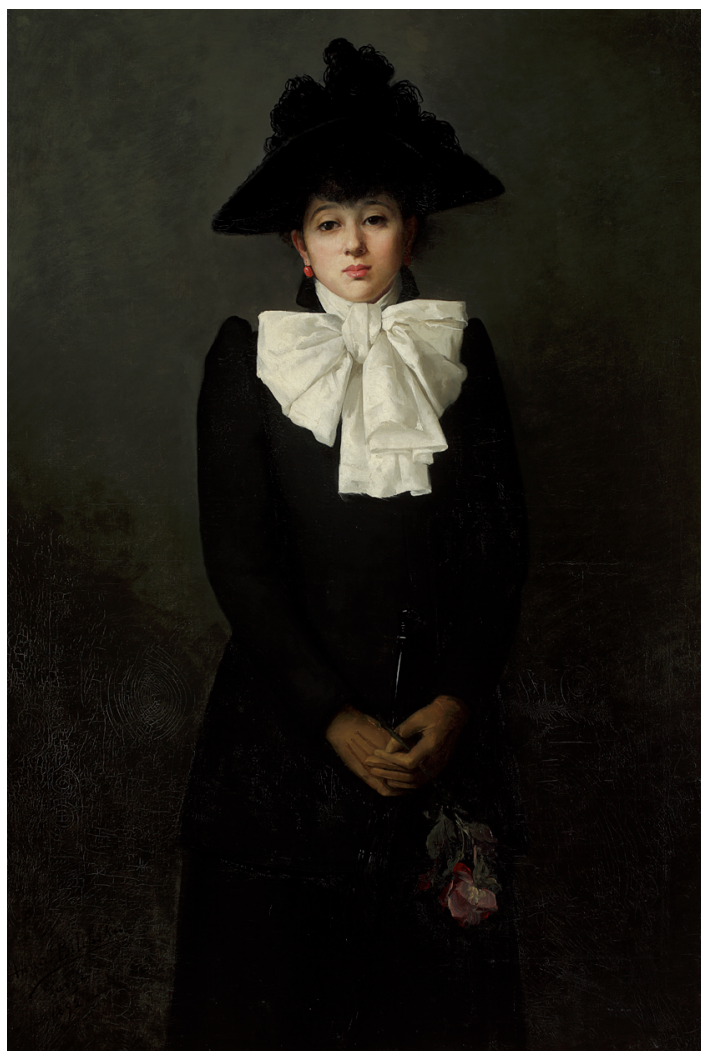

Anna Bilińska-Bohdanowiczowa, Portret młodej kobiety z róża w ręku

Fot. Piotr Ligier. Ze zbiorów Muzeum Narodowego w Warszawie

\footnotetext{
${ }^{6}$ E. Słowacki, Prawidla wymowy i poezji wyjęte $z$ „Dziet”, Wilno 1826, s. 177-178.
} 
Zdaniem Piotra Chmielowskiego pierwszą polską biografię opartą na źródłach, „krytyczną", jak to określił, stanowił Żywot Jana Karola Chodkiewicza pióra Adama Naruszewicza z roku 1781. Prawdziwym czasem biografii stał się jednak - zdaniem badacza - dopiero wiek XIX, dostarczając metod wszechstronnej analizy źródeł, pozwalającej na stworzenie pełnego obrazu opisywanej postaci, bez popadania w tryb kronikarski lub apologetyczny. Jako wybitnych biografów wymienia Chmielowski m.in. Juliana Bartoszewicza (Znakomici mężowie polscy XVIII wieku, t. 1-2, 1836); Karola Szajnochę (sylwetki wielu osobistości, m.in. Wacława Potockiego, Krzysztofa Opalińskiego, Barbary Radziwiłłówny, publikowane w czasopismach, wyd. osobne Szkice historyczne, t. 1-4, 1854-1869); Adama Jerzego Czartoryskiego (Żywot Juliana Ursyna Niemcewicza, 1860); Antoniego Małeckiego (Jan Andrzej Morsztyn, poeta polski XVII wieku i jego imiennicy, 1859; dodajmy jeszcze monografię Juliusz Stowacki, jego życie i dzieła w stosunku do wspótczesnej epoki, t. 1-2, 1866-1867); Lucjana Siemieńskiego (Żywot Franciszka Morawskiego z jego listów ułożony, 1867); i innych - Waleriana Kalinkę, Stanisława Tarnowskiego, Klemensa Kanteckiego, Kazimierza Morawskiego, Ferdynanda Hoesicka?

Pisząc o unikaniu przez dziewiętnastowiecznych biografów narracji kronikarskiej i podkreślając stosowaną przez nich krytykę źródeł, sygnalizował Chmielowski doskonałą orientację w dziełach biografistyki dawniejszej. Odejście od prymatu zdarzeń i analiza materiałów źródłowych były bowiem odpowiedzią na preferowane w okresie od starożytności do wieku XVIII modele narracji. Biografie dawniejsze nie stroniły od ujęć mitologicznych, a nierzadko, jak u Plutarcha, dotyczyły postaci mitycznych, w późniejszej zaś biografistyce - bohaterów półlegendarnych lub zupełnie fikcyjnych, stanowiących, jak np. Lukrecja, ucieleśnienie cnót niewieścich. Skoro Chmielowski umieścił biografię w dziale prozy służącej odtwarzaniu prawdy przeszłości, konsekwentnie sygnalizował obowiązującą w dojrzałej postaci tego gatunku wierność zgromadzonym faktom, „psychologiczne wniknięcie w głąb usposobienia i charakteru”, bezstronność oceny ${ }^{8}$. Dawna narracja kronikarska, odsyłająca do jednego z modeli biografii średniowiecznej i renesansowej, który opis charakteru zastępował rejestrem czynów opisywanej postaci, nie spełniała tych kryteriów. Z kolei w czasach odrodzenia w narracji biograficznej zaznaczył się udział wzorów retorycznych, one de facto, a nie zgodność z zasadami prawdopodobieństwa, decydowały o prawdziwości przekazu. Historiografia renesansowa, podobnie jak jej antyczny odnośnik, stanowiła gałąź retoryki, a biografia, gatunek pograniczny wobec literatury pięknej i historii, dziedziczył obligacje spoczywające na obu tych dziedzinach, szczęśliwie unikając wewnętrznej kolizji dzięki temu, że w estetyce renesansowej to, co prawdziwe, miało wartość estetyczną ${ }^{9}$. Ten pozorny paradoks wyostrza, niejako od innej strony, Roland Barthes, pisząc o dawnych przekazach historiograficznych: „sama »rzeczywistość« staje się kluczowym odniesieniem w narracji historycznej, której zadaniem jest sprawozdanie z tego, »co się naprawdę zdarzyło «, i która nadaje znaczenie niefunkcjonalnym szczegółom, jeśli tylko denotują one »to, co miało miejsce «: »konkretna rzeczywistość « staje się wystarczającym uzasadnieniem wypowiedzi” ${ }^{\prime 0}$. Postawa taka, brak oporu wobec „rzeczywistości”, a raczej tego, jak ją sobie

\footnotetext{
7 P. Chmielowski, Stylistyka polska wraz z nauką kompozycji pisarskiej, Warszawa 1903, s. 341-342.

8 Ibidem, s. 341.

9 K. Pomian, Historia między retoryką a teologią. Niektóre problemy myśli historycznej doby Odrodzenia i reformacji, „Odrodzenie i Reformacja w Polsce” 1964, t. IX.

10 R. Barthes, Efekt rzeczywistości, tłum. M. P. Markowski, „Teksty Drugie” 2012, nr 4, s. 123.
} 
wyobrażano (stąd cudzysłów), realizowała się kosztem zasady prawdopodobieństwa. Jeśli dodać do tego obowiązującą w biografistyce parenezę i troskę o moralny wydźwięk prezentowanych sylwetek i historii, trzeba uznać przednowoczesną postać tej gałęzi piśmiennictwa za królestwo pięknych, wzniosłych i zupełnie niezwykłych opowieści. Jednocześnie, jak zauważyła Hanna Dziechcińska, stanowiły one swoiste laboratorium dla form powieściowych. Badaczka podkreśla różnice między konstrukcją bohatera biografii a usytuowaniem i ukształtowaniem bohatera powieściowego, podobnie jak różnice między prozą dawną a współczesną ${ }^{11}$. Ta ostrożność jest zrozumiała i zasadna, ale samo wprowadzenie rozważań na temat relacji biografia-powieść sugeruje pewną wspólnotę poszukiwań i problematyzacji, łączącą oba gatunki, do której jeszcze powrócimy.

\section{3.}

Wielu dziewiętnastowiecznych odnowicieli gatunku biograficznego Żmichowska znała osobiście i niepodobna, by nie czytała ich prac z tej konkretnej dziedziny. Z Julianem Bartoszewiczem, współpracownikiem „Przeglądu Naukowego”, gdzie opublikowano przypominam - i Pogankę, i Książkę pamiątek, mogła spotykać się na sobotnich wieczorach u Anny i Hipolita Skimborowiczów, stanowiących w latach 40. grono jej najbliższych przyjaciól, jak też w samej redakcji, którą Skimborowicz, Hipcio, zarządzał pod nieobecność Edwarda Dembowskiego. Siemieńskiego poznała w Poznaniu w roku $1844^{12}$, przedstawial się już wówczas jako „wyznawca towianizmu”, ale fakt ten nie wpłynął na ocenę jego talentu poetyckiego, jaką w liście do Anny Kisielnickiej wystawiła mu autorka Poganki: „jak ci napisze pełnym sercem zwrotki jakie, to byś i płakała, i dumniała nad ojczyzną twoją"13. Kilkanaście lat później w liście do Bibianny Moraczewskiej nazwie Siemieńskiego słodko Lucusiem i przedłoży przyjaciółce prośbę o dostarczenie jego wierszy, do których muzykę miał napisać Antoni Woykowski, mąż głośnej literatki - Julii Woykowskiej ${ }^{14}$.

Działalnością i osobą Karola Szajnochy interesowała się Żmichowska dosłownie przez całe życie. W latach 50. polecała siostrzenicy, Marii Rostworowskiej, lektury autorów krakowskich i lwowskich: „Postaraj się o Kremera, Bielowskiego, Borkowskich Duninów, nade wszystko Szajnocha zdrowy jest i toniczny" ${ }^{15}$. W ostatnim (zachowanym) liście do brata, Erazma Żmichowskiego wspomina o projektowanej i nieodbytej wycieczce w Tatry: „obiecywano mi nawet znajomość i wspóltowarzystwo Karola Szajnochy”16. Izabelę Zbiegniewską zapytywała schorowana już pisarka: „A nie słyszałaś też co o ostatnim dziele Szajnochy: Dwa lata z dziejów polskich, od 1646 do 1648 ?"17.

\footnotetext{
11 H. Dziechcińska, Biografistyka staropolska w latach 1476-1627 (kierunki i odmiany), Wrocław-Warszawa-KrakówGdańsk-Łódź 1971.

12 Odwołuję do informacji podanej w biogramie pisarza przez M. Romankównę, zob. Stownik biograficzny, do: N. Żmichowska, Listy, t. 1: W kręgu najbliższych, do druku podała i komentarzem opatrzyła M. Romankówna, Wrocław 1957, s. 709.

13 N. Żmichowska, Listy, t. 1, s. 343 (list z 11 czerwca 1844 roku).

14 Eadem, Listy, t. 2: Rozdroża, Wrocław 1960, s. 142 (list z 12 września 1859 roku).

15 Eadem, Listy, t. 1, s. 253 (list z 28 kwietnia 1854 roku).

6 Ibidem, s. 217 (list z 2 i 3 czerwca 1868 roku).

17 Eadem, Listy, t. 3: Miodogórze, Wrocław 1967, s. 113 (list z 4 listopada 1872 roku).
} 
Świadectwo swego zainteresowania monografią Antoniego Małeckiego o Słowackim pozostawiła w liście do powstańca roku 1863 i sybiraka, Henryka Wohla:

Byłam raz na kilka dni tylko w Warszawie, gdy spotkałam się z tą książką, nocy nie dosypiałam, a musiałam całe dwa tomy przeczytać. Bardzo rozumnie napisana, chociaż to dziwne robi wrażenie, kiedy się spotyka z takim spokojnym, prawniczym, pedagogicznym i urzędowym sądem o Słowackim! Ale rzecz zdrowa, nie bardzo w psychologii subtelna, tym właściwsza zatem na pokarm dla młodych, nie dość gruntownych umysłów. Swoją drogą zabawnie wygląda owa fantazja cyrklem obowiązków i codziennej moralności mierzona, diament według cech krystalografii opisany. Wiele prócz tego szczegółów objaśniających najpiękniejsze poemata, wyjątki z listów tłomaczące człowieka, a cudne on listy pisał ten Słowacki. Pogodziłam się z jego osobistością, względem której pomimo wielkiej wdzięczności niewielką czułam sympatię, doskonale też widzieć prawie można, jakim procesem chemicznym w owe umysły z powszechnej kolei życiem i naturą wysadzone towianizm się przelewał, ile dobrego im przyniósł na ich własną korzyść, ile złego na szkodę nas wszystkich wyrządził. Małecki na to wszystko ma sąd, nie powiem księdza, ale urzędnika katolickiego, ciągle mi się zdawało, jak gdyby pisał ze względem na zajmowane miejsce, by mu katedry nie odebrano, co zresztą jest dość prawdopodobnym i możliwym, gdy sobie przypomnimy, iż we Lwowie przebywa. Trzeba nawet uznać, że rozsądnie postąipi $1^{18}$.

Monografia historycznoliteracka nie była ścisłą realizacją narracji biograficznej, ale wywód biograficzny zajmował w pracy Małeckiego istotne miejsce. Dzięki otrzymanym za pośrednictwem Karola Szajnochy listom Słowackiego historyk zdecydował się na przemyślane rozbudowanie i udokumentowanie narracji biograficznej, co w latach 60. XIX wieku stanowiło na gruncie raczkującej dopiero u nas nauki o literaturze swoisty ewenement. Ewenementem była też sama próba interpretacji dzieł wieszcza, ujęta w rygory zdyscyplinowanego wywodu. Żmichowska świetnie rozpoznała novum, czyli założenia narracji historycznoliterackiej, jednocześnie wyłuskała z tekstu biografa ideologiczne koncesje na rzecz konserwatywnej publiczności literackiej, która - jak wolno przypuszczać - stanowiła większość nie tylko we Lwowie. Możemy się jedynie domyślać, że te wygładzone przez Małeckiego ustalenia dotyczyły np. reakcji Słowackiego na Psalmy przyszłości Krasińskiego, romantycznej frenezji ujawnionej w dramatach, sporu z Mickiewiczem. Nie to jednak ma dla nas istotne znaczenie.

Ciekawy jest inny kontekst biograficzny, który Żmichowska dołącza do omówienia monografii Małeckiego. Wydawałoby się - sprawa bez znaczenia. W tym samym liście do Wohla wspomina pisarka córki niejakiego Augusta Emanuela Glücksberga, warszawskiego księgarza, Paulinę Plewińską i Krystynę Berkmanową, oraz trzecią, niewymienioną $\mathrm{z}$ imienia i nazwiska. Utalentowane kobiety (Paulina była zdolną pianistką) nie cieszyły się dobrym zdrowiem. Zagrożone „chorobą piersiową” spędzały dużo czasu we Włoszech. Tam, być może w Pizie, gdzie „szczęśliwie trafily na maleńkie kółeczko polskiego towarzystwa"19, poznały Marię Wodzińską, muzę Słowackiego i Chopina. Informacja ta wywołuje w Żmichowskiej falę wspomnień i refleksji szczególnego rodzaju. Po pierwsze, zauważa, iż

18 Ibidem, s. 252-253 (list z 12 czerwca 1869 roku).

19 Ibidem, s. 252 (podstawowe informacje na temat rodziny Glücksbergów czerpię ze Stownika biograficznego, dołączonego przez M. Romankównę do trzeciego tomu listów Żmichowskiej). 
Maria Wodzińska nie poślubiła żadnego ze swoich wspaniałych adoratorów, ale wyszła za mąż za pospolitego „głupca”. Po drugie, zakłada, że:

serce pewną edukację przebywa, bo po dawniejszych swoich wielbicielach nie mogła z nim [pierwszym mężem - dop. G. B.] wytrzymać, rozwiodła się i została żoną znacznie młodszego od siebie, lecz widać stosownie wybranego człowieka. Kiedy do dzisiejszego dnia kochają się jak kochankowie i są szczęśliwi jak młodość - a niemłodzi, niemłodzi! ${ }^{20}$

Żmichowska wie, co mówi, bo peregrynując po wielu miejscowościach, w których mieszkali członkowie jej rodziny, poznała obu mężów Marii Wodzińskiej (hrabiego Józefa Skarbka i Władysława Orpiszewskiego) albo przynajmniej drugiego z nich - dzierżawcę majątku Skarbków (list tego nie precyzuje). Nawet zatańczyła z nim mazura! O WodzińskiejOrpiszewskiej pisze wprawdzie, że „gra ślicznie, maluje bardzo też wdzięcznie”, ale zauważa także, iż Słowackim Maria Wodzińska chyba nie bardzo się później interesowała, skoro dopiero panny Glücksberg poinformowały ją o monografii Małeckiego, której została bohaterką - przynajmniej na tych kilku stronach dokumentujących pobyt poety w Szwajcarii w latach 1834-1835. Dwutomowe dzieło Małeckiego Maria Wodzińska czym prędzej zamówiła. „[C]iekawam jednak - zastanawia się pisarka - czego się zeń nauczy, a można bardzo wiele nauczyć"21.

Właśnie: czego można było się nauczyć z monografii Małeckiego, czego mogła nauczyć się z niej Maria Wodzińska? I dlaczego Żmichowska dopełniła rozważania o życiu i twórczości Słowackiego gawędziarskim aneksem niewielkiej, wydawałoby się, wartości? Tym bardziej że Małecki przestrzegał przed watowaniem pustki informacyjnej ploteczka$\mathrm{mi}^{22}$. I jakie znaczenie miał ten komentarz w kontekście poszukiwań biograficzno-powieściowych prowadzonych przez autorkę Poganki?

W Przedmowie do swego dzieła Antoni Małecki czuje się w obowiązku wytłumaczyć, iż tak obszerną pracę poświęca komuś, kto zajmuje tylko „skromne stanowisko pisarza”23, nie będąc nawet największym poetą! Wskazuje na dwa powody: obfitość materiału biograficznego, zawartą w wybitnej korespondencji autora Balladyny. I to, że nawet pewna ułomność, rozpoznana u Słowackiego, ma charakter pokoleniowy, a nie jednostkowy. "Już przeto dla tej jednej przyczyny uważam życie jego za przedmiot pod każdym względem godny głębszego rozpatrzenia" ${ }^{24}$. Na uwagę zasługuje też diagnoza, kryjąca w sobie definicję odkrytej niedoskonałości: „Między dziełami, których ostatecznie dokonał, a tą potęgą jego poetyc-

20 Ibidem

21 Ibidem.

22 A. Małecki, Przedmowa, do: idem, Juliusz Stowacki, jego życie i dzieła w stosunku do współczesnej epoki, t. 1, Lwów 1866, s. XV.

23 Ibidem, s. IX.

24 Ibidem, s. XIII. 
kiej zdolności, która w pojedynczych tylko miejscach bije u niego całym blaskiem świetności, gdzieniegdzie zaś tylko »dymi przez słowa «, nie ma należytego stosunku”25.

Przedmowa pokazuje trudny los prekursorów, tych, co przecierają nieznane szlaki. Małecki zmaga się nie tylko z legendą Mickiewicza i (a może przede wszystkim) Krasińskiego, ale także z utrwalonymi poprzez edukację klasyczną wzorami dawnej biografistyki, której bohaterami pozostawali ludzie niekwestionowanej wielkości - wojownicy, władcy, słowem: znakomici mężowie. W tle tych odpieranych zawczasu pytań i zarzutów (dlaczego powstała biografia poety) tkwią dawne wzory gatunkowe, zaczerpnięte z ujęć kronikarskich i apologetycznych. Słowackiego nie dało się wpisać w żadną z tych formul. Jego geniusz pracował kapryśnie, okoliczności życia nie porywały. Kształtujący się dopiero etos romantycznego poety przegrywał na tym polu z pamięcią reguł zaktualizowanych w klasycznym gatunku. Albo raczej zmagał się z nią. Być może biografia Mickiewicza przeważyłaby w tym sporze. Biografia Słowackiego, opisywana w połowie lat 60. XIX wieku - nie miała takich szans. Dlatego autor monografii stworzył inną ścieżkę dostępu do swego bohatera - poprzez doświadczenie pokoleniowe, przywołując tę kategorię być może po raz pierwszy w dziejach polskiej historii literatury; doświadczenie, które, zdaniem Małeckiego, skazuje prawie wszystkich poetów tej generacji (generacji wygnańców?) na sinusoidalne wahania nastrojów i zróżnicowany poziom dokonań. $\mathrm{Z}$ tego rozrzutu największych możliwości i najdotkliwszych słabości wynika wspomniany brak „należytego stosunku” między jednym a drugim.

W jakimś stopniu brak owego stosunku wynika również, choć Małecki o tym nie pisze, z zastosowania biograficznej narracji, opartej na listach. W szczególnie wyrazisty sposób listy ujawniają rozrzut między wzlotami poetyckiej imaginacji a codziennością, która może być wspaniale opisana, ale ciągle pozostaje przestrzenią zwyczajności. Dlatego Małecki szuka dodatkowych uzasadnień dla swego dzieła i swojej metody - dysharmonia Słowackiego jest ważna, bo dotyczy nie tylko jego samego. Jest ważna, bo powtarzalna. Prawidłowość jednego życia to za mało, ale wielu biografii - to już coś.

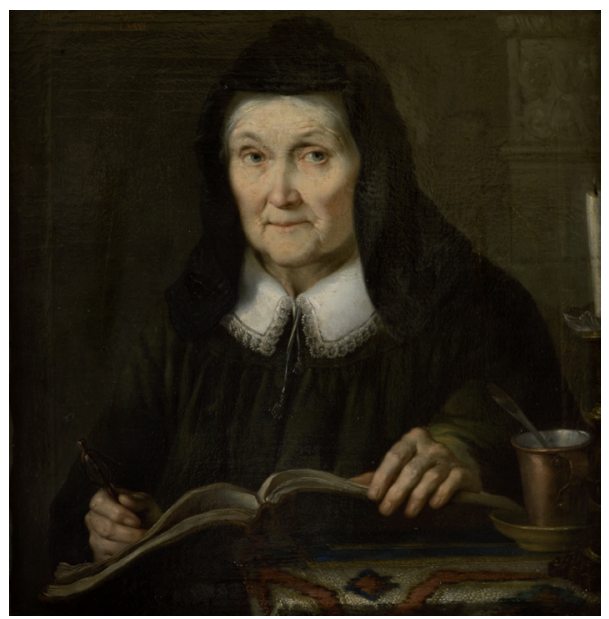

Rafał Hadziewicz, Portret Julii Hadziewiczowej

Fot. Pracownia Fotograficzna Muzeum Narodowego w Krakowie.

Ze zbiorów Muzeum Narodowego w Krakowie

25 Ibidem, s. XII-XIII. 
Czy do takich wniosków miała dojść również Maria Wodzińska? Raczej nie. Żmichowska trochę przygania jej, zauważając, iż - przy wszystkich swoich talentach artystycznych i intelektualnych - nie wie, co się „u nas dzieje” (czy używa tego określenia w znaczeniu: w Polsce, czy raczej: po sąsiedzku - tego nie rozstrzygniemy). Passus odnoszący się do Marii Wodzińskiej, secundo voto - Orpiszewskiej stanowi, być może, przewrotną formę zbudowania żywota równoległego na wzór wynalazku Plutarcha. O dydaktycznej wartości dzieł biograficznych Żmichowska była przekonana; lekturę Plutarcha i pedagogiczne pogadanki biograficzne, m.in. drukowane anonimowo w „Magazynie Powszechnym” w latach 1834-1835 przez Kazimierza Brodzińskiego, polecała swym kuzynkom i uczennicom ${ }^{26}$.

Ale tym razem chodziło nie o dzieci, lecz o dorosłych. Biografia Słowackiego została napisana, pozostało pytanie, jak na tym tle rysuje się biografia domniemanej bohaterki poematu W Szwajcarii? Wodzińska nie została towarzyszką życia ani Słowackiego, ani Chopina. Czy jej biografia na tym straciła? Żmichowska zdaje się sugerować, że nie. Że romantyczne wzory kochania, które być może roztaczał przed nią poeta na szczytach Alp, uwielbienie, którym ją darzył, mając zresztą pewnie na myśli tylko drżenie własnego serca i własnej wyobraźni ${ }^{27}$, przekuła na poczucie własnej wartości; zawalczyła o niezależność i prawo do miłości. Rozwiodła się z hrabią Skarbkiem, co było w tamtej epoce czynem wymagającym odwagi, i poślubiła człowieka niższego stanu, co było równie zaskakujące (Orpiszewski pełnił funkcję dzierżawcy w dobrach hrabiego). W dodatku kochali się!

Żmichowska pochłonęła książkę Małeckiego, ale sama interesowała się typem innej biografii, co niejasno i wyrywkowo zarysowała w cytowanym liście do Henryka Wohla, a co w pełnej krasie pojawi się w bibliografii jej tekstów pisanych w latach 60. i 70.

\section{5.}

Innej - to znaczy jakiej? „Trzeba przedstawić powieść jako Autobiografię zastanawiającej się nad soba kobiety" - pisała w notatce adresowanej do Wandy Grabowskiej, matki BoyaŻeleńskiego ${ }^{28}$. Notatki tej nie znał Chmielowski, publikujący dzieło Żmichowskiej Czy to powieść? w ostatnim tomie zbiorowego wydania jej dzieł w roku 1886. Nie było jej również, oczywiście, w pierwodruku („Wiek” 1876, nr 268 - 1877, nr 30, z przerwami), ani w pierwszym wydaniu osobnym z roku 1877. Dlaczego notatka, znaleziona przez Boya w papierach po matce, trafiła jako rodzaj przedmowy, wprowadzenia do tej właśnie powieści? Stało się tak, ponieważ w korespondencji Żmichowskiej z Grabowską temat nowej powieści, nowej w znaczeniu: kolejnej, i nowej w sensie: innej niż dotychczasowe realizacje gatunku, pojawia się jako swoisty leitmotiv wielu listów pisanych do młodej przyjaciółki (jej odpowiedzi zachowały się w postaci szczątkowej). Na tej podstawie możemy stwierdzić, iż notatka wiązała się z utworem, który stanowił przepracowaną wersję pomysłu, z jakim około roku 1867 Żmichowska zwróciła się do swojej uczennicy i wielbicielki w odpowiedzi na jej projekty

\footnotetext{
26 Zob. list do Marii Rostworowskiej, [w: ] N. Żmichowska, Listy, t. 1, s. 267-268 (list z 8 grudnia 1866 roku).

27 O egoizmie poety, gotowego wystawić wszystko na sprzedaż, pisała Narcyza Żmichowska w opowiadaniu Capriccio, [w: ] eadem, Wolne chwile Gabryelli, t. 1 (dalsze się nie ukazały), Poznań 1845.

28 Eadem, Czy to powieść?, z przedmową Boya-Żeleńskiego, Warszawa 1929. W tym wydaniu powieści Boy zamieścił wspomnianą notatkę.
} 
pracy literackiej. Wanda, pasowana przez Narcyzę na współautorkę planowanego dzieła, wycofała się z kooperatywy. Żmichowska ostatecznie sama przystąpiła do pracy, przełamując apatię i niechęć, niemożność pisania, jakie dręczyły ją od chwili wyjścia z więzienia.

$\mathrm{W}$ połowie lat 60 . we wspólnej pracy nad nową formułą powieści widziała autorka Poganki jedyną drogę wyjścia z kryzysu - osobistego (apatia) i artystycznego (postrzegany przez nią impas form powieściowych, ich daleko posunięta konwencjonalizacja). Istotne znaczenie miała też intencja czysto altruistyczna - chęć pomocy młodej, ambitnej, przywiązanej do pisarki dziewczynie, która szukała swego miejsca w świecie i lokowała nadzieje w pracy naukowej, przekładowej i artystycznej, nie mając zresztą ku temu wybitnych zdolności.

A więc: autobiografia zastanawiającej się nad sobą kobiety. Proponując takie ujęcie tytułu lub tematu, Żmichowska przywiązuje wagę do każdego słowa. Świadomie używa sformułowania „zastanawiająca się nad sobą” kobieta, a nie konkurencyjnych, i ostatecznie odrzuconych, określeń: kobieta „patrząca w siebie - rozglądająca się w sobie”. Uważa, iż zaproponowane ujęcie lepiej oddaje jej intencje. Intencje, jak można przypuszczać, dalekie od czystej intymistyki, od zagłębiania się we własne i tylko własne wnętrze. Także „[z] ewnętrzne tylko fakta, osobowa fotografia powinna być zakazaną lub unikaną przynajmniej”29, precyzuje pisarka. I wyjaśnia, o jaką autobiografię idzie tutaj gra, jaka autobiografia ma powstać w rezultacie tych zabiegów: „A u t o b i o g r a fi a nie twoja, Wando, nie moja, ale nasza, i kilku innych" ${ }^{30}$. Formuła ta wyznacza wąski, precyzyjnie wymierzony, zakres pisarskiej wolności: autorka musi nadać rzetelnej wiedzy o świecie, a nie tylko o swoim wnętrzu, postać wypełnioną, ale nieprzeciążoną osobistymi konkretami; postać wykraczającą poza własne źródła inspiracji, własną pamięć, własne doznania. Przedstawiona fabuła nie powinna stanowić prostego odwzorowania przeżytej lub zaobserwowanej sytuacji, ale też nie powinna być bajką lub opowieścią tendencyjną, co jest „między wszystkimi naszymi autorkami upowszechnioną metodą" ${ }^{\text {'1 }}$, pisała Żmichowska. Jak można przypuszczać, to „Zastanawianie się nad sobą” ma stanowić czynnik najważniejszy dla zrozumienia nowej formuly powieści, której celem jest szukanie prawdy o świecie, tego, „czym jest [prawda przyp. G. B.] w n a s, moja Wando, nawiasem mówiąc"32.

Wypracowane przez Żmichowską ujęcie jest nie tylko oryginalnym pomysłem autorskim, jest też kołem ratunkowym rzuconym całemu gatunkowi: krytycy, publicyści „[s]łusznie po większej części łają książkom i literaturze, za to, że w głowach przewraca, że egzaltuje, że zdrowy sąd o rzeczach krzywi; jest w tym racja; tylko nie ma racji, gdy żądają zupełnego zniesienia tej gałęzi r o m a n s e m zwanej"33. Żmichowska częściowo przyjmuje krytykę powieści, jaka przewijała się przez całe stulecie, ale odnosi ją przede wszystkim do zużytych form narracyjnych. Tymczasem powieść może i powinna mieć inną przyszłość: „Zostanie ona i musi zostać, bo jest zdolna wytworzyć bardzo potrzebną odroślę: przyczynek coraz bogatszy i rzeczywistszy do psychologicznych badań" ${ }^{34}$. Z pozoru formuła ta nie brzmi odkrywczo. Żmichowska zdaje sobie z tego sprawę. Mało to się w powieści napsy-

\footnotetext{
29 [Notatka] włączona do: N. Żmichowska, Czy to powieść?, s. XXX.

30 Ibidem, s. XXIX-XXX (podkreślenie autorki).

31 Ibidem, s. XXX.

32 Ibidem, s. XXXII.

33 Ibidem, s. XXXI (podkreślenie autorki).

34 Ibidem.
} 
chologizowano? Pisarki nie interesuje jednak psychologia jako zbiór obserwacji szczegółowych, jednostkowych; jej zdaniem taka metoda odpowiada naturze nauk ścisłych. Powieść musi szukać dla siebie innych sposobów gromadzenia i przedstawiania wiedzy o świecie, bardziej kontrastywnych, bardziej krytycznych, zestawiających rozmaite obserwacje, a zarazem zachowujących pamięć prawd ogólnych: „Prawdy się szuka ciągłym porównywaniem, rozmierzaniem, ważeniem ideału przez rzeczywistość, a rzeczywistości przez ideał”35.

Żmichowska objaśnia swoje rozumienie nowej formy powieściowej na konkretnym przykładzie: miejsca miłości w życiu kobiety. Zaprzeczyłabym własnemu doświadczeniu, gdybym napisała, że to temat drugorzędny albo bardzo specjalny. Był i jest ważny. Żmichowska podaje wyjściową zasadę: nie należy wychodzić za mąż bez uczucia. Pamiętamy, jaką rangę w jej hierarchii wartości mają miłość i namiętności, nawet złe, grzeszne. „Gdybym ja to mial, mówi Beniamin w Pogance, choć zniszczeniem i tajemnicą, to bym miał”. Ale nie ma. Aspazja już go nie pragnie. Gra skończona, napisałam kiedyś, komentując jego cierpienia ${ }^{36}$. Pamiętamy, co na temat świętości uczuć pisała Narcyza w listach, np. do Bibianny Moraczewskiej i innych korespondentów, ona cicha saintsimonistka. Ale, zauważa Żmichowska, szeroka praktyka społeczna, doświadczenia wielu rodzin podsuwają nam argumenty, które artysta rozważający fenomen miłości powinien wziąć pod uwagę. Że nie zawsze uparte czekanie na wielkie uczucie jest twórcze i sensowne. Że kierując się tylko szacunkiem, można stworzyć udaną rodzinę, zyskać duchową i materialną stabilizację. Wiele kobiet potrafi samodzielnie utrzymać się, ale praca nie da im tego, „co jest w życiu najdroższe i najpotrzebniejsze: nie da obowiązków rodzinnych" ${ }^{37}$. Co można - zdaniem pisarki uczynić z tą wieloperspektywiczną prawdą o miłości? Pokazać jej komplikacje, zawęźlenia, konsekwencje. Co istotne, nie uchylając ideału, który czeka na swoje spełnienie.

Uważna, otwarta na świat autorka ma - jak wynika z notatek Żmichowskiej - ważne zadanie do spełnienia. Z jakichś względów łatwiej jej niż twórcy płci męskiej oprzeć się presji obowiązujących regul, ich uzurpatorskiej treści, niezależnie od tego, czy chodzi o miłość, czy inne kwestie. Tymczasem:

[p]ół-skłonnostki, pół-poczciwostki, pół-prawdeczki snadniej sobie w życiu radzą, osiągają cośkolwiek, czynią choć trochę czegoś użytecznego, majątek na czas jakiś (niewiele takich, którzy dla siebie na całe życie i dla dzieci, by też na dwa pokolenia zrobiony) zachowują. Wszystko jest fluktuacją, nieoznaczonością, ruiną, co w gruzy się rozsypuje; a swoją drogą nad gruzami jeszcze się niebo nie załamało; wśród gruzów są dusze pokutujące, które pragną; są nawet, które mają astronomiczną pewność, że jutro słońce musi zaświeciciç ${ }^{38}$.

Skoro życie jest ciągiem zmian, klęsk i nadziei, trzeba niezmienność ideału, stabilność, atrakcyjność zasad stale konfrontować z praktyką społeczną, z rozwiązaniami rzeczywiście stosowanymi. Także tymi obowiązującymi w sztuce. Żmichowska przestrzega przyjaciółkę przed przesadną metaforyzacją języka, przed wybujałością artystyczną, którą nazywa „hulactwem, próżniactwem, marnotrawstwem”, „obłędami romansowymi”, które wyrażają

\footnotetext{
35 Ibidem, s. XXXII.

36 G. Borkowska, Wstęp, do: N. Żmichowska, Poganka, wstęp i opracowanie G. Borkowska, wyd. 3, BN I 121, Wrocław 2013, s. LX.

37 Ibidem, s. XXXIII.

38 Ibidem, s. XXXV.
} 
tylko temperament autorski, przed ciągłym poszukiwaniem zdradzającym brak celu życiowego ${ }^{39}$.

Powieść „zastanawiającej się nad sobą kobiety” musi dopuścić do głosu tę „średnią wartość życia", jak się wyraził Prus, relacjonując wystawę malarstwa rosyjskiego w Warszawie ${ }^{40}$, tak jak formuła nowej autobiografii, która nie zakłada wędrówki w głąb psychiki autora, musi uwzględniać doświadczenia cudze, odtworzone w praktyce życia, zapisane w pamięci zbiorowej. Wydaje się, że cel wytyczony przez Żmichowską jest niesłychanie trudny do zrealizowania, prawie niemożliwy. Pisać o świecie, tak jak jest on rozumiany przez artystę, artystkę, niepodążającą jednak za głosem własnego serca, a nawet umysłu, ale za potrzebą obiektywizacji własnych pragnień poprzez konfrontację z cudzymi doświadczeniami, historiami, fabułami. Tak mniej więcej rysuje się wąskie pole wolności, jakie Żmichowska pozostawia piszącej kobiecie.

\section{6.}

Pomijam w analizie drugą część notatki, z 19 stycznia roku (prawdopodobnie) 1867; odnosi się ona do nieco innych aspektów relacji, łączącej Żmichowską z jej przyjaciółką. Chcąc pozostać przy opozycji powieści i biografii, przy wzajemnym stosunku obu tych gatunków wypowiedzi, przechodzimy do drugiego tekstu (aneksu) przypisanego utworowi Czy to powieść? Chodzi o Plan utworu p.n. „Czy to powieść?”, według edycji Chmielowskiego z roku 1886, czyli do wyimka, który w wydaniu powieści z roku 1929 nosi tytuł Kontur ogólny. W przypisie dołączonym do aneksu edytor, Tadeusz Boy-Żeleński stwierdzał: „Kontur ten, będący planem zamierzonej całości, zamieszczono w zbiorowych wydaniu Pism Żmichowskiej z r. 1886 (Tom V) z przypiskiem: »Z rękopisu Żmichowskiej udzielonego przezJ.B [Julię Baranowską - przyp. G. B.] «. Otóż w papierach matki znalazłem rękopis tego Konturu, przeznaczony dla mojej matki i jej przesłany przez Narcyzę (patrz Przedmowa). Ponieważ rękopis ten różni się w wielu miejscach od tekstu wydania z r. 1886, uważałem za właściwe niedokładności skorygować, a miejsca opuszczone przywrócić”41. Boy miał rację. Plan powieści, pozostający w papierach Wandy Grabowskiej, był nieco bogatszy od pierwodruku. Nie ulega wątpliwości, iż w wersji udostępnionej Chmielowskiemu przez Baranowską poczyniono drobne zmiany, które służyły zatarciu dialogiczności wypowiedzi, jej adresywnego charakteru. Z Konturu opublikowanego w roku 1886 zniknęły nawiasowe wtrącenia, w których Żmichowska zwracała się bezpośrednio do Wandy Grabowskiej, proponując jej jakieś rozwiązania lub komentując własną wypowiedź. Usunięcie nawiasowych treści lub usunięcie samych nawiasów (ich graficznych ekwiwalentów), zmienia nieznacznie nie tyle sens, ile pragmatyczny aspekt wypowiedzi, adresowanej przez Żmichowską do wskazanego, ujawnionego w tekście odbiorcy, a właściwie odbiorczyni. Zmienia też charakter sformułowanych uwag: nie stanowią spójnej teorii, o ich doniosłości decyduje nie sama ranga pomysłu intelektualnego, ale zbliżenie solidarnie współpracujących ze sobą autorek.

\footnotetext{
39 Ibidem.

40 B. Prus, rubryka Korespondencje „Kraju”, Al. G., „Kraj” 1884, nr 5, s. 8.

${ }^{41}$ N. Żmichowska, Czy to powieść?, s. 267.
} 
Skoro powieść ma prezentować prawdę, a prawda jest „punktem stycznym ideału z rzeczywistością" ${ }^{2}$, to dialog, negocjowanie sensów, jest naturalnym miejscem jej narodzin. Notatka Narcyzy stanowi więc „teoretyczny” komentarz do powieści, i zarazem samą powieść in statu nascendi. Ponieważ nie wolno nam przeoczyć tych kilku nawiasowych uwag, decydujących o dialogiczności wypowiedzi (apostrofy do Wandy, uwagi do niej kierowane), bierzemy za podstawę edycję Boya, dbając - dla porządku i pewności - o skonfrontowanie jej kształtu z rozwiązaniami przyjętymi wcześniej przez Chmielowskiego.

Co znajdziemy w Konturze powieści? Odpowiedź na najważniejsze pytanie, decydujące o doniosłości rozwiązań narracyjnych zarysowanych przez Żmichowską: jak pisać powieść, by pozostała ona (auto)biografią. Nie moją, nie twoją, ale n a s z ą, i kilku jeszcze innych? Budując zarys planowanej powieści, Żmichowska wskazuje na pewne elementy fabularne i realia historyczne, które mogłyby - jej zdaniem - tworzyć osnowę utworu. Realia te pozostają w bezpośrednim związku z jej własną biografią (tradycje patriotyczne domu, wczesne sieroctwo, edukacja w czasie pobytu na pensji pani Wilczyńskiej, skomplikowane relacje z bratem/braćmi, lektury romantyczne), ale nie są jej powtórzeniem. Narcyza przepuszcza własne doświadczenia przez sito ogólnej wiedzy o świecie historycznym ówczesnej Polski (koniec XVIII wieku do połowy następnego stulecia). Między innymi „nawiasowo” pisze:

(Miałam wielką pokusę dać bratu rolę prawdziwego opiekuna i obrońcy, dlatego że mój brat był zawsze wsparcie moim, ale z doświadczenia przekonałam się, iż to u nas do wyjątków należy. Większość, jeśli nie wszystkość braci, których znałam - mówię nawet o kochających swoją rodzinę - zawsze częściej była praktycznie ratowana przez siostry, niż co by sióstr ratunkiem być była powinna. Składały się na to okoliczności polityczne i dziedziczny charakter narodu, w którym żeński pierwiastek jest więcej udoskonalony w rodzaju swoim od pierwiastka męskiego w swoim znów rodzaju). Lepiej zatem ogólniejszych i powszechniejszych trzymać się pierwowzorów ${ }^{43}$.

Tak powstaje „książka pamiątek” o pokoleniu 1820, za młodym, by wziąć udział w powstaniu listopadowym, ale dostatecznie dorosłym, by je pamiętać i przeżywać młodzieńcze egzaltacje, podsycane etosem walki i patriotyczną legendą. To, że Narcyza była podatna na tego rodzaju uczucia, potwierdza decyzja włączenia do fabuły powieści - samobójczej śmierci jednego z bohaterów, ojca rodziny (jej własny był uczestnikiem insurekcji kościuszkowskiej), który strzela do siebie w Ogrodzie Saskim. Jest rok 1821 i gest ten, niewyjaśniony (pisarka dodaje tylko, sygnalizując niejednokrotność takich zachowań: to nie byli samobójcy z rozpaczy, ale z oburzenia), odsyła do osnowy dramaturgicznej Kordiana, 1834, i do innego utworu Słowackiego - Poema Piasta Dantyszka herbu Leliwa o piekle, 1839, a więc do wyraźnych, choć niewypowiedzianych, motywacji patriotycznych ${ }^{44}$. Dalsze elementy tej fabuły, rozwinięte potem (nie zawsze w zgodności z Konturem, tj. którąkolwiek jego wersją) w tekście powieści, obejmują paralelę siostra-brat. Chłopiec, choć sierota, wyposażony przez rodzinę, idzie do szkól; dziewczynka zostaje w domu, gdzie „robi pończochę” i uczy

\footnotetext{
42 Ibidem, s. XXXIX.

43 N. Żmichowska, Kontur ogólny, dodany do: eadem, Czy to powieść?, edycja Boya, s. 272.

44 „Nie zabijali się Polacy prawi! / Ani przed dumną Kościuszki mogiłą, / O takiej rzeczy kiedy słychać było, / A teraz przyszło nam jak na ostatki, / Że się na trupach samobójczych matki, / Kładną” (J. Słowacki, Poemat Piasta Dantyszka herbu Leliwa o piekle, Paryż 1839, s. 44-45).
} 
się francuskiego od guwernantki, a czytania i pisania od życzliwego oficjalisty. Uczy się tak pilnie, że na imienny ciotki pisze powinszowania „z głowy”, co budzi podziw. Żmichowska dotkliwie ironizuje, dodając, iż epoka była tak jałowa w talenty literackie, że nawet tłumaczeniem poematu Światynia Wenery w Knidos, oryginał pióra Charles-Louis de Secondata Montesquieu, przekład Józefa Szymanowskiego, można się było wkupić do nieśmiertelności.

Siostrze towarzyszy więc opinia utalentowanej autorki, ale - równocześnie - biednej i w dodatku nieładnej kobiety. Bohaterka zamieszkuje z bratem, wspólnie gospodarują, ona stara się, chwytając przygodnie dostarczane książki, ciągle pogłębiać swoją wiedzę. Odrzuca propozycje małżeńskie. Tymczasem brat żeni się niefortunnie z kobietą piękną i kapryśną. Siostra wspiera brata w czasie trwania nieudanego związku. Ten umiera na tyfus, powierzając siostrze opiekę nad żoną i synem. Z bratową siostra nie umie się porozumieć, bratankiem zająć się nie może: „Moralne zobowiązanie bez kodeksowego prawa”45.

Tak prezentują się cztery części planowanej powieści. Sugerowane detale i zdarzenia stanowią przetworzoną wersję biografii Narcyzy, przetworzoną podwójnie; autorka wplata w fabułę nie tylko to, co przeżyte, ale i to, co zasłyszane i przeczytane; komentując dzieje własnej rodziny, nieznacznie je koryguje, upiększa. Powieściowy „brat” wciela cechy charakteru oraz zachowania Janusza i Hiacynta Żmichowskich, szczególnie pierwszego z nich. Janusz, o którym mało wiemy, został przez Narcyzę w nawiasowych komentarzach zmitologizowany jako opiekun i wzór rozsądku. Zdaje się, że w rzeczywistości nieobca mu była nuta szaleństwa i straceńczego temperamentu, gdy tymczasem pisarka rzutuje na niego, oświetlony autorytetem Hegla, idealny model stosunków łączących brata z siostrą, o którym filozof pisał:

Natomiast stosunek [etyczny] pozbawiony domieszki [czynnika naturalnego] ma miejsce między bratem a siostrą. Są oni tej samej krwi, która jednak doszła w nich do [stanu] spokoju i równowagi. Dlatego brat i siostra nie pożądają siebie nawzajem, ani jedno drugiemu nie dało tego bytu dla siebie, ani też [jedno od drugiego go] nie otrzymało, lecz są wobec siebie nawzajem wolnymi indywidualnościami. Dlatego kobiecość [das Weibliche] w postaci siostry ma najwyższe przeczucie [Ahnung] istoty etycznej; do jej świadomości i rzeczywistości ta kobiecość [es] nie dochodzi, gdyż prawo rodziny jest wewnętrzna istotą, która istnieje sama w sobie - nie jest ona wydobyta na światło dzienne świadomości, lecz pozostaje wewnętrznym uczuciem [Gefühl] i uwolnioną od rzeczywistości boskością ${ }^{46}$.

I dalej:

Brat jest zaś dla siostry spokojną, równą istotą, a uznanie jej jest u niego czyste, nie miesza się ze stosunkiem przyrodniczym; dlatego obojętność jednostkowości i jej etyczna przypadkowość nie występują w tym stosunku, lecz moment uznającej i uznawanej jednostkowej jaźni może utrzymywać tu swoje prawo, ponieważ związany jest z równowagą krwi i pozbawionego pożądania stosunku. Dlatego utrata brata stanowi dla siostry stratę niepowetowaną, a jej obowiązek wobec niego - obowiązek najwyższy ${ }^{47}$.

45 Ibidem, s. 275.

46 G. W. F. Hegel, Fenomenologia ducha, 1807, tłum. Ś. F. Nowicki, Warszawa 2010, s. 295 (I wyd. w tym tłum. 2002; pierwsze pol. w tłum. A. Landmana, t. 1-2, 1963-1965).

47 Ibidem, s. 296. 
Żmichowska interesowała się filozofią Hegla i myślą heglowską w Polsce, skoro już w 1842 roku wspominała o tym w liście do przebywającej w Berlinie Heleny Turnowej ${ }^{48}$. Czy wielokrotnie przez nią przywoływana androgyniczna pełnia, jaką bez udziału uczuć erotycznych, uosabia bliskość brata i siostry, była pokłosiem tej lektury? Na pewno natomiast Żmichowska znała powieść François-René Chateaubrianda, René, 1805, dramat osieroconego młodzieńca, zakochanego z wzajemnością w swej siostrze. W liście do trzeciego brata, Erazma Żmichowskiego, bawiła się stwarzanymi przez siebie pozorami (?) i reakcją na nie ze strony otoczenia: „Śmiać mi się chciało nawet, jak wujenka Józefowa opowiadała mi historię w guście René Chateaubrianda, by mnie przestrzec nieznacznie, że siostra w bracie pokochać się może" $\mathrm{e}^{49}$. To, co wiemy na pewno: Chateaubriand sparafrazował w powieści swoją biografię, i Żmichowska zaproponowała to samo, odwołując się jednak szeroko do kontekstu pokoleniowego i społecznego. Bardzo intensywnie odczuwana i bardzo mocno podkreślana więź z braćmi, a nie - z bratem ${ }^{50}$ (obok serdecznych relacji z siostrami), wynikała nie tyle z perwersyjnych upodobań, ile z poczynionych obserwacji: kobiety mogły przekazać mężczyznom siłę charakteru, którą tamci gdzieś zagubili (to częsta opinia powtarzana w odniesieniu do epoki międzypowstaniowej), mężczyźni mogli zapewnić kobietom prawo do aktywnego działania, którego one potrzebowały. W tej sytuacji wzajemne wsparcie było sprawą chwili.

W Konturze ogólnym Żmichowska zapisała rady dotyczące konstrukcji wspomnień rodzinnych, wychodząc z następującego spostrzeżenia:

Niektóre powieściopisarki angielskie zaczynają historię swoich bohaterów od historii kilku nieraz wstępnych generacji; w utworach sztuki jest to rzeczą trochę zbyteczną, ale w rzeczywistych lub przynajmniej, o ile być może zbliżonych do rzeczywistości, autobiografiach, takie sprawozdanie genealogiczne jest nawet obowiązkiem ${ }^{51}$.

W tym zdaniu pisarka raz jeszcze sygnalizuje odrębność gatunkową planowanego dzieła i odrębność tego typu powieści, który uważa za godny poszukiwań. Dalej, nawiązując być może do modnego genetyzmu, podkreśla rolę naturalnego i społecznego otoczenia, w którym wyrasta człowiek. Nie jest on bowiem monadą, ale „kombinacją, do której przeszłość

\footnotetext{
48 N. Żmichowska, Listy, t. 1, s. 297 (list z 18 lutego 1842 roku): „O Berlinie tak wiele sprzecznych zdań styszałam, a szczególniej pod względem wychowania. Część oświeceńszej młodzieży, która sama jest cząstką bardzo małą, bardzo nieznaczną naszej Warszawy, stamtąd przyniosła nowe systemata i wyobrażenia. Jest między nimi wiele zdolności, wiele dobrych chęci, zdaje się, że do najpiękniejszego zmierzają celu, jednakże wśród reszty znaleźli wielu przeciwników. Któż może lepiej o tym sądzić jak matka, i to jeszcze taka jak ty matka, która w tejże samej sferze ma umysły swoich dzieci kształcić”.

49 Ibidem, s. 71.

50 Kiedy zarzucano Żmichowskiej zbyt ostentacyjnie okazywaną miłość do braci, odpowiadała: „Ja temu bynajmniej nie przeczę i gdybym miała tylko jednego z was bratem, to bym już głowę za nim z miłości traciła; lecz ja mam trzech takich, a o każdym z osobna mogłabym przysiąc, że go najlepiej kocham, i o każdym prawdę bym powiedziała” (N. Żmichowska, Listy, t. 1, s. 71; list z 8 sierpnia 1838 roku).

${ }^{51}$ N. Żmichowska, Kontur ogólny, dodany do: eadem, Czy to powieść?, s. 276.
} 
rodziców, wpływy świata zewnętrznego wchodzą i przedstawiają konieczność, a zdolność tworzenia, zmieniania i wyboru przedstawia wolną wolę"52.

Żmichowska zdawała sobie sprawę z tego, że wpływ środowiska na jednostkę i jej wytwory został potwierdzony przez filozofów i socjologów, np. Taine’a, ale wiedziała też o tym, co inni pomijali w swoich rozważaniach, iż zakres tego oddziaływania jest wciąż nieokreślony, „stanowi ogromną masę niewiadomych XXX”. z przyczyny, o której już wspominaliśmy, odwołując się do notatki sporządzonej ok. roku 1867. Nagromadzenie wielu faktów nie zawsze pozwala na odtworzenie kierunku ich przepływów. Brakuje „nitek i żyłek”, które łączyłyby oderwane obserwacje w jakąś całość. Co więcej, niemożność skomponowania takiej całości powoduje rezygnację z pewnych istotnych elementów układanki: w sporze wolności z koniecznością, odpowiedzialności moralnej z wrodzonymi skłonnościami obcinamy niewygodne prawdy, niepasujące do naszej teorii, jak nitki, pozostające po zakończonym szyciu.

Żmichowska uważała, że społeczeństwo polskie znajduje się w położeniu szczególnym, że:

między dojrzałymi i dorastającymi w tej chwili generacjami, wszystkim brakuje tradycji, osobistej, rodzinnej tradycji - nitki się porwały śmiercią lub apatią, całe thumy sierot musiały się bez ojców i matek chować - od stu lat (za dwa lata) jedna warstwa po drugiej załamywała się i tylko pamięć ogólnej katastrofy można było przechowaćs ${ }^{54}$.

Polska tradycja rodzinna została porwana; z wygody, strachu, bólu, by zaoszczędzić sobie upokorzenia - zaniechano rozmów o przeszłości, o dziedzictwie. Rzeczy osobiste, ślady kultury materialnej i artystycznej, np. konterfekty malowane po domach przepadty w zniszczonych dworach i dworkach. Żmichowska upomina się o rekonstrukcję pamięci, zaleca, by to, co szczęśliwym trafem zachowało się, zebrać i dokładnie studiować, porównywać, poddawać refleksji: „z takich ram odmalować należy, tylko wiernie, babkę i dziadka, zwróć Lavaterowską uwagę na rysy, a z kompleksji, z tuszy, z kolorytu fizjologiczne wyprowadź wnioski”ss.

Te fragmenty Konturu często traktowano jako podstawę do wskazania angielskich powieściopisarek i angielskiej powieści-sagi jako wzoru podsuniętego przez Żmichowską do naśladowania. Nie jest to wniosek właściwy. Pisarka odrzuca powieść, jeśli rozumieć przez to określenie utwór fikcyjny, choćby dysponował rozbudowanym zapleczem rodzinnym. Odwołanie się do faktów biograficznych, potwierdzonych zdarzeń, twardego konkretu (obraz, konterfekt, wspomnienie, dokumenty, opowieści rodzinne i zapiski) ${ }^{56}$ stanowi warunek sine qua non wskazanej drogi narracyjnej.

52 Ibidem, s. 276-277.

53 Ibidem, s. 277.

54 Ibidem, s. 278

55 Ibidem, s. 279.

56 Żmichowska posłużyła się tą metodą w sposób wzorcowy w rozprawie o sławnym kuzynie, N. Żmichowska, O Pawle Edmundzie Strzeleckim wedtug rodzinnych i towarzyskich wspomnień, „Ateneum” 1876, t. 1; nadbitka. Pisałam o tym eseju w artykule G. Borkowska, Sir Edmund i Lord Jim. O wspomnieniu rodzinnym Narcyzy Żmichowskiej, [w:] Album gdańskie. Prace ofiarowane Profesorowi Józefowi Bachórzowi na siedemdziesiąta piątą rocznicę urodzin i pięćdziesięciolecie pracy nauczycielskiej, red. J. Data i B. Oleksowicz, Gdańsk 2009. 
Mamy więc w bibliografii pism Żmichowskiej trzy co najmniej teksty poruszające podobny temat: relację między powieścią a biografią. Jeden powstał w końcu lat 50., kiedy pisarka przygotowywała zbiorową edycję swych dzieł (komentarz zamykający wydanie Ksią̇ki pamiątek w oficynie Jana Jaworskiego); dwa następne - w drugiej połowie lat 60. lub nieco później, kiedy pisarka, najpierw z Wandą Grabowską, a potem sama, pracowała nad ostatnim, niedokończonym utworem - Czy to powieść? Można jednak powiedzieć, że problem nadrzędny i źródłowo związany z biografią - problem celów i granic sztuki (narracyjnej) nurtował ją od wczesnej młodości. W latach 40 . Żmichowska była pełna krytycyzmu wobec samego etosu poety romantycznego. Widziała w sztuce źródło złych ambicji, egoizmu, opacznie pojętej wolności, pogardy dla życia jako takiego. Z czasem skonkretyzowała swoje zainteresowania; skupiła się na powieści i poszukiwaniu dla niej nowej formuły. Jeśli recenzja książki Józefa Korzeniowskiego Spekulant miała być miarą stosunku Żmichowskiej do sztuki narracyjnej epoki międzypowstaniowej, to ocena ta wypadła raczej słabo ${ }^{57}$. Pisarka $\mathrm{w}$ roli krytyka, posłużywszy się ironicznym stylem i drobnymi mistyfikacjami, zarzuciła powszechnie podziwianemu autorowi mielizny umysłowe, uleganie powieściowym schematom.

Badaczka twórczości Żmichowskiej, Maria Woźniakiewicz-Dziadosz, chce widzieć w jej wypowiedziach metatekstowych akces do toczonej w czasach międzypowstaniowych dyskusji o powieści. Wskazuje na podobieństwa łączące stanowisko Żmichowskiej i m.in. Józefa Ignacego Kraszewskiego (w utworze Dwa światy, 1855, pisarz zaznacza, że wypadki powieściowe powinny urywać się tak, „jak w życiu naszym urywają się”), ale też podkreśla dzielące ich różnice: stopień skomplikowania konstrukcji utworu jest u Żmichowskiej znaczniejszy i polega na przeniesieniu ciężaru ideowego z warstwy fabularnej na partie dyskursywne $^{58}$. Maria Woźniakiewicz zwraca też uwagę na inne polemiki literackie tego czasu; ich osią jest spór o społeczne obligacje ciążące na gatunku powieściowym (wzięli w nich udział prawie wszyscy wybitniejsi krytycy; z jednej strony Edward Dembowski, Antoni Marcinkowski, Leszek Dunin-Borkowski, Józef Ignacy Kraszewski, zwolennicy mniej lub bardziej akcentowanych społecznych funkcji gatunku; z drugiej - Fryderyk Henryk Lewestam, August Cieszkowski, obrońcy funkcji estetycznych) ${ }^{59}$.

Bogata korespondencja Żmichowskiej zaświadcza o jej dobrej orientacji w tematyce sporów literackich, ale autorka Poganki pozostaje konsekwentnie na ich obrzeżu. Jej własna koncepcja powieści jako (auto)biografii zastanawiajacej się nad sobą kobiety wykracza poza opozycję realizm-estetyzm, wartości społeczne-wartości estetyczne, nie tylko dlatego, że - jak pisze Woźniakiewicz-Dziadosz - Żmichowska dyskursywizuje narrację oraz osłabia

57 [N. Żmichowska], O najnowszej powieści J. Korzeniowskiego pt. „Spekulant”, „Przegląd Naukowy” 1846, t. 3, nr 27. Analizowałam tę wypowiedź w artykule: G. Borkowska, Ganić chwaląc, chwalić ganiąc. Narcyzy Żmichowskiej krytyka literatury, [w: ] Dyskursy krytycznoliterackie 1764-1918. Wokót „Stownika polskiej krytyki literackiej”, red. G. Borkowska i M. Rudkowska, Warszawa 2010.

58 M. Woźniakiewicz-Dziadosz, Między buntem a rezygnacją. O powieściach Narcyzy Żmichowskiej, Warszawa 1978, s. 204. Ustalenia Marii Woźniakiewicz wspierają klasyczne ujęcia metaliterackiej aktywności pisarzy i krytyków epoki międzypowstaniowej, prace A. Bartoszewicz, St. Burkota, J. Bachórza, E. Owczarz, ostatnio artykuł A. Martuszewskiej, Józef Ignacy Kraszewski między romansem a powieścią, [w:] Kraszewski - poeta i światy, red. T. Budrewicz, E. Ihnatowicz i E. Owczarz, Toruń 2012 (a także wypowiedzi M. Strzyżewskiego i E. Kasperskiego z tego samego tomu).

59 Ibidem, s. 205-213. 
wagę i funkcję elementów fabularnych ${ }^{60}$, ale przede wszystkim dlatego, że ta dyskursywizacja w niczym nie przypomina konwencjonalnych wtrętów moralistycznych, pojawiających się w literaturze tego czasu. Wewnątrzpowieściowe dygresje nie prezentują jasno sformułowanego przesłania moralnego, nie uczą niczego poza tym, że świat jest skomplikowaną grą, którą trzeba prowadzić w sposób uczciwy, na własną odpowiedzialność. Dlatego nie sam udział we wczesnym etapie sporu o realizm i nawet nie powrót do odrzucanej w tym czasie nadobecności narratora, ale wyjście poza te kwestie lub ich ujęcia - w zupełnie inną, samodzielnie skonstruowaną stronę, uważam za decydujące dla postawy Żmichowskiej.

Jak bardzo pisarka nie ułatwiała zadania rozumiejącego odczytania jej tekstów, świadczą wymienione przed chwilą wypowiedzi na temat opozycji powieść-biografia. Bo choć mówią na ten sam lub podobny temat, wcale nie są jednobrzmiące. Tekstom późniejszym poświęciliśmy już sporo uwagi. Przypomnę tylko konkluzję; chodzi o powieść rozumianą jako (auto)biografia kobiety, reprezentantki określonego pokolenia. $\mathrm{W}$ tej formule narracyjnej doświadczenie własne jest konfrontowane $\mathrm{z}$ udokumentowaną historią rodzinną i z doświadczeniami innych ludzi. Kobiecość jest tu gwarancją solidności wykonania odpowiedzialnej pracy, która wiąże się z gromadzeniem faktów, dokumentów, opowieści, rekwizytów.

Co pojawia się w tekście wcześniejszym, czyli w cytowanym na początku artykułu komentarzu do edycji Książki pamiątek w roku 1861? Przekonanie, że biografia, przeciwstawiona powieści, różni się od niej tym, że jest dziełem otwartym, nie skończonym. Biografia - to „forma” in statu nascendi, pozbawiona dystansu wobec życia, przylegająca do niego jak koszula do ciała. Można wręcz powiedzieć, że biografia to samo życie, jak i tocząca się w miarę rozwijanych nici opowieść na jego temat. Powieść i biografię dzielą nieprzekraczalne różnice: autor powieści dąży (powinien dążyć) do spójności, podmiot biografii do wzbogacenia swego wnętrza. Powieść skupia się na faktach, biografia - ma inny kierunek, zmierza do celu etycznego, doskonałości moralnej, zbawienia.

Co stanowi część wspólną tych, tak różnych, wypowiedzi Żmichowskiej? Czy w ogóle jest jakaś część wspólna? Komentarz z Ksiażki pamiątek podkreśla bezsilność formuł powieściowych wobec otwartości biografii, jej permanentnego tworzenia się, które sprawia, że póki życie trwa, niczego konkluzywnego nie możemy o nim powiedzieć. Wbrew wszystkiemu, o czym przekonuje współczesna Żmichowskiej nauka („Cuvier z jednego zęba wywnioskował całą postać mamuta" ${ }^{1}$, ironicznie zaznacza), nie potrafimy przewidzieć, czym „to” się skończy, tzn. jak zachowają się ludzie w konkretnej sytuacji, jak zniosą presję okoliczności zewnętrznych, czy sprostają wyzwaniom. Możemy przerobić „długi szlafrok na obcisły kaftanik" ${ }^{2}$, zamykając w gotowych schematach nieprzewidziany bieg naszego lub cudzego życia, ale będzie to jednoznaczne z odejściem od ujęcia biograficznego na rzecz powieściowości. Biografia nie może uchylić się od odpowiedzi na kluczowe pytanie: czy sprostaliśmy własnemu losowi? Czy sprostaliśmy, ale nie schematom, tylko moralnym zobowiązaniom wobec bliźniego i nas samych, naszego poczucia sensu istnienia. Bez tego

60 Ibidem, s. 208: „Zarówno w konserwatywnej, jak i demokratyzującej krytyce okresu występuje wyraźnie, choć nigdzie wprost nie sformułowane przekonanie, iż »tendencja«, czyli »intencja« powieści powinna się wyrażać nie w wypowiedzi narratorskiej, ale wyłącznie poprzez kompozycję materiału fabularnego. Fabuła więc ma być jedynym nośnikiem znaczeń ideowo-moralnych".

61 N. Żmichowska, Pisma, t. 3, s. 126.

62 Ibidem, s. 127. 
rozpoznania biografia jako „gatunek” nie ma racji bytu, a tymczasem konkluzji nie można w wielu przypadkach sformułować, bo często jesteśmy na nią niegotowi, bo naruszałaby interesy innych osób. Dlatego Żmichowska nie kontynuuje Książki pamiątek, dlatego w ogóle nie garnie się do pisania. Bo jeśli - z wielu względów, przede wszystkim ludzkich, a nie np. cenzuralnych - nie można napisać tego, co należy napisać, to lepiej odłożyć pióro: „Ach! Niechaj śpią w pokoju dawni znajomi moi ... żadnego z nich nigdy nie upokorzę, nie zawstydzę, na niekonsekwencji lub na kłamstwie wierutnym nie schwycę..."63.

Nie ulega wątpliwości, że wątki soteriologiczne i etyczne w biografizujących koncepcjach Żmichowskiej, sformulowanych w latach 50. (biografia jako historia zbawienia), wynikają z jej doświadczenia więziennego. Aresztowanie, śledztwo, ponad półtoraroczny pobyt w zamknięciu, przesłuchania, dochodzące ją informacje o zachowaniu innych więźniów - to przeżycia decydujące o nowym stosunku pisarki do ludzi i sztuki narracyjnej. Czy sprostałam? Czy sprostali? - to pytania zasadnicze. Dlaczego jedni - tak, a drudzy - nie? Dlaczego słabsi udźwignęli swój krzyż, a silni - upadli? Czy chcą i mogą odkupić swoje winy? To jest właśnie ta „niedowidziana, niedosłyszana, niedocieczona, wewnętrzna historia zbawienia", którą należałoby umieścić w biografii.

Gdyby było można.

Nie przeczy tej interpretacji, a przynajmniej nie obala jej całkowicie - odczuwany już we wczesnej młodości - opór Żmichowskiej wobec pisania. Jak pamiętamy, jeszcze przed uwięzieniem, w lutym 1848 roku, Żmichowska tłumaczyła się przed czytelnikami „Przeglądu Naukowego” ze zwłoki w publikacji kolejnych odcinków Książi pamiątek. Podtrzymując fikcyjną rolę edytorki utworu, która niefrasobliwie zagubiła część cudzego dzieła, pisała:

Ej, chyba ja koniec dokomponuję i dadzą mi spokój - ale to nie tak łatwo, jak się zdaje, kończyć cudze myśli, a dopieroż zgadywać rozwinięcie cudzego życia wydarzeń - dla mnie szczególniej, com nigdy w całokształt powieściowy mojego własnego nie osnowała pomysłu. Jakie tu robić zastosowanie, jakie połączenie tych osób, które w Książce pamiątek spotkały się Bóg wie na co i dlaczego. Roiły mi się wprawdzie tysiączne przypuszczenia i milionowe możebności - ale gdym je chciała ująć w sztuczne wyrobienie - jedno z drugim nie trzymało się wcale. Bo też zapewne czytelnicy sami od dawna już spostrzegli, jaki brak sztuki jest w tej książce pamiątek najpierw nie ma jedności, zaokrąglenia, wybitności żadnej - imiona po imionach, obrazki po obrazkach, rozmowy po rozmowach się snują - a dramatyzmu, mistrzostwa, tego mistrzostwa, co to w pochwyconym przedmiocie każdy szczegół łączy z całością, każdy środek z celem tego mistrzostwa, co wykończa, harmonizuje, stwarza, z ciągle przytomnym samemu sobie zamiarem, tego mistrzostwa śladu, próżno by chciał kto dopatrzyćc ${ }^{64}$.

Trudność pisania wynikała m.in. z tego, że Żmichowska nie podjęła żadnej z przetartych ścieżek narracyjnych, które w latach 40 . XIX stulecia obejmowały na gruncie polskiej powieści chociażby narracje gawędowe, romans historyczny, powieść obyczajową, wariacje hoffmannowskie. Najbliższa była sternizmowi, ale i tutaj się nie odnalazła, może z powodu zbyt dużej dawki ludyczności, jaką serwował angielski autor. Po epizodzie konspiracyjno-więziennym odwrót od uprawianych form powieści, jako zaprzeczających jej doświadcze-

63 Ibidem.

64 [N. Żmichowska], Usprawiedliwienie się wydawczyni „Książki pamiątek”, „Przegląd Naukowy” 1848, R. VII, nr 10 (z 10 kwietnia 1848 roku), s. 6-7. 
niom pisarskim i ludzkim, jej poglądom na sztukę i świat, stał się wręcz niezbędny. Ani czysta fantastyka, ani powieść szlachecka, ani dylematy świata mieszczańskiego - nie zbliżały do rozwiązania istotnych dylematów etycznych. Urągały rzeczywistości i pamięci.

Wydaje się, że przygotowując dziesięć lat później prolegomenę do utworu biograficznego (Czy to powieść?), pisarka zdążyła porzucić traumatyczną przestrzeń wspomnień. Że zaczęła oddychać nowym życiem. Że uległa rozpowszechnionemu przekonaniu, iż wyjaśnienia wszelkich zjawisk należy szukać w ich genezie, a skonwencjonalizowane schematy powieściowe - zastąpić twardym materiałem dokumentarnym. Tak poniekąd było. Ale bez wątku polskiego, bez odniesienia do historii utraconej wolności i utraconej, na skutek okoliczności dodatkowych (circonstances attenuantes) - więzi pokoleniowej, ta nowa formuła autobiografizmu wyglądałaby pewnie inaczej. Biografia w wersji wypracowanej przez Żmichowską miała ratować pamięć historyczną dotykającą jednak nie tyle wojen i zbrojnych czynów, ile życia społecznego, zogniskowanego na dziejach rodziny. Miała być pamięcią podtrzymywaną raczej przez kobiety niż mężczyzn. Bo to kobiety, zdaniem pisarki, były nośnikami trwałych relacji rodzinnych, międzyludzkich, które składały się na tkankę życia. Jedynie one mogły odwrócić niedobrą sytuację, w której „dzieci bardzo mało o rodzinie wiedzą i najczęściej nie wiedzą tego, co jest najważniejsze do wiedzenia”65. „Synowie się rozsieli w napoleońskich wojnach od Madrytu do Możajska”"6 ale babki, matki i córki były na miejscu i mogły, rozeznawszy się w tej szczególnej sytuacji, wziąć sprawę (polską i ludzką) w swoje ręce.

Narcyza przyswoiła zasady dziewiętnastowiecznego genetyzmu, i wyciągnęła $z$ tej nauki radykalne wnioski. Jeśli o rozwoju dorosłego osobnika decydują jego początki, zamierzchła przeszłość całego gatunku, poprzednie pokolenia, to dla wspólnego dobra trzeba tę historię przywrócić naszej pamięci, poskładać z ułamków wspomnień i rzeczy. Taki cel postawiła Żmichowska w latach 60 . XIX wieku przed nową powieścią polską. Wciąż nie wierzyła gotowym schematom fabularnym, ale - co jest rozpoznawalne w strukturze ostatniego utworu - zdaje się nie odrzucała już nadziei, że poprzez konfrontację własnych doświadczeń z doświadczeniami pokoleniowymi można dążyć ku pewnej hipotezie całości. Tak jakby kiedyś wykpione „mistrzostwo śladu” stawało się znów możliwe do podjęcia.

\section{9.}

Powrócę na chwilę do rzuconej wcześniej uwagi na temat analogii między biograficznością Żmichowskiej a biosem historii według Berenta. „Bios historii tworzą [...] ludzie w określonych wymiarach swych biografii. Kształtują go swą działalnością polityczną, swymi postawami moralnymi, twórczością i wyborami światopoglądowymi - wszelkim typem aktywności włączającej jednostkę w życie społeczne" - pisał monografista Opowieści biograficznych ${ }^{67}$, nawiązując bezpośrednio do definicji Berenta, który precyzował, iż chodziło: „o ży w e namiętności o n y c h czasów i ludzi w t e d y działających (raz jeszcze: nie o lo -

65 Eadem, Czy to powieść?, edycja Boya, s. 278.

66 Ibidem, s. 279.

67 W. Bolecki, Wstęp, [w:] W. Berent, Nurt. Diogenes w kontuszu. Zmierzch wodzów, wstęp, oprac., dodatek krytyczny W. Bolecki, Kraków 1991, cyt. z wyd. 2: Kraków 2000, s. 12. 
g o s, lecz o b i o s historii)"68. Chodziło także o dokumenty, utrwalone wypowiedzi przeciwstawione ustalonym interpretacjom, legendom, utartym definicjom. „Biografia jako fakt historii i kultury, los jednostkowy jako oznaka i symbol przeżyć zbiorowości - oto kontury Berentowskiego biosu. W jego centrum tkwiła jednak zagadka - prawda o ludziach zagrzebana pod stosami dokumentów, przeinaczona przez legendy i fałszywych świadków, nigdy nie utrwalona we wszystkich szczegółach, nigdy niemożliwa do całościowej rekonstrukcji”' ${ }^{69}$ - dodawał Włodzimierz Bolecki.

Ale obok interpretacji Boleckiego dysponujemy innym odczytaniem Berentowskiej trylogii (Nurt, Diogenes w kontuszu, Zmierzch wodzów). Stefan Treugutt w brawurowym eseju Fides, Spes, Caritas zarzuca Berentowi, nazwanemu mieszczańskim Plutarchem niepodległej ojczyzny, brak wyobraźni historycznej, potknięcia faktograficzne, omyłki (liczne, jak pisze), brak zrozumienia dla działań militarnych: „Ba, to w ogóle leżało poza sferą jego zainteresowań, poza jego wyobraźnią. A jego wyobraźnia nie umiała poruszać się wśród zjawisk i danych realnej historii, nie była to wyobraźnia historyka, ale historiozofa, i to szczególnie uformowanego historiozofa, lepiej nawet rzec: mitografa. Mitografa inteligencji polskiej"70. I dalej: „Berenta w ogóle nie interesuje historia w swym niegdyś przebiegu autentycznym, a to, co nazywa on »bios historii «, charakteryzując swą postawę w tzw. opowieściach biograficznych, to najdalsze jakiejś biologicznej naturalistyczności w odtwarzaniu dziejów - to raczej życie »duszy gromadom ludzkim wspólnej «"71. Według Treugutta jedne legendy zastąpił Berent innymi, budując zmitologizowany rodowód polskiej inteligencji, traktowanej nie jako grupa spełniająca określone kryteria socjologiczne, ale jako wspólnota emocjonalno-duchowa, i pasując inteligencję, wywiedzioną z różnych tradycji i warstw społecznych, na dysponenta świadomości narodowej.

Czy podobny rozrzut opinii, spowodowany w dodatku podobnymi okolicznościami (poszukiwanie nowej formuły dla opowiedzenia dziejów Polski porozbiorowej), nie był udziałem Żmichowskiej? Posługując się kluczem politycznym, odczytywano jej twórczość jako świadectwo zaangażowania konspiracyjnego, potem, znów upraszczając, traktowano jako radykalny manifest feministyczny. Wydaje się, że ani jedna, ani druga interpretacja nie wytrzymuje próby czasu. Pisarka szukała odpowiedniej formuły dla dzieł wyrastających z etosu patriotycznego, który rozumiała jednak inaczej niż twórcy emigracyjni i inaczej niż pisarze międzypowstaniowi. Miał on stanowić element tradycji domowej, rodzinnej, osobistej, własnej. Dlatego kierowała się w stronę biografii, opowieści nieoficjalnej, utrwalonej często poprzez los - pozostających na obrzeżach „wielkiej” historii - kobiet.

\section{Bibliografia}

Barthes Roland, Efekt rzeczywistości, tłum. Michał Paweł Markowski, „Teksty Drugie” 2012, nr 4. Bolecki Włodzimierz, Wstęp, [w:] Wacław Berent, Nurt. Diogenes w kontuszu. Zmierzch wodzów, wstęp, oprac., dodatek krytyczny W. Bolecki, Kraków: Wydawnictwo Literackie, 2000.

\footnotetext{
68 Ibidem, s. 373 (podkreślenie Berenta).

${ }^{69}$ W. Bolecki, op. cit.

70 S. Treugutt, Fides, Spes, Caritas, „Teksty Drugie” 1992, nr 4, s. 147.

71 Ibidem, s. 149 (formula cytowana pochodzi z Oziminy Berenta).
} 
Borkowska Grażyna, Ganić chwaląc, chwalić ganiąc. Narcyzy Żmichowskiej krytyka literatury, [w:] Dyskursy krytycznoliterackie 1764-1918. Wokót „Stownika polskiej krytyki literackiej”, red. Grażyna Borkowska i Magdalena Rudkowska, Warszawa: Fundacja Akademia Humanistyczna:Instytut Badań Literackich PAN, 2010.

—, Sir Edmund i Lord Jim. O wspomnieniu rodzinnym Narcyzy Żmichowskiej, [w:] Album gdańskie. Prace ofiarowane Profesorowi Józefowi Bachórzowi na siedemdziesiąta piąta rocznicę urodzin i pięćdziesięciolecie pracy nauczycielskiej, red. Jan Data i Bolesław Oleksowicz, Gdańsk: Wydawnictwo Uniwersytetu Gdańskiego, 2009.

—, Wstęp, do: Narcyza Żmichowska, Poganka, wstęp i oprac. Grażyna Borkowska, wyd. 3, BN I 121, Wrocław: Zakład Narodowy im. Ossolińskich, 2013.

Chmielowski Piotr, Stylistyka polska wraz z nauką kompozycji pisarskiej, Warszawa: nakł. Gebethnera i Wolffa, 1903.

Dziechcińska Hanna, Biografistyka staropolska w latach 1476-1627 (kierunki i odmiany), WrocławWarszawa-Kraków-Gdańsk-Łódź: Zakład Narodowy im. Ossolińskich-Wydawnictwo Polskiej Akademii Nauk, 1971.

Hegel Georg Wilhelm Friedrich, Fenomenologia ducha, tłum. Światosław Florian Nowicki, Warszawa: Fundacja Aletheia, 2010.

—, Fenomenologia ducha, t. 1-2, przekł., wstęp Adam Landman, Warszawa: Państwowe Wydawnictwo Naukowe, 1963-1965.

Krasicki Ignacy, Zbiór potrzebniejszych wiadomości porządkiem alfabetu ułożonych, t. 1, Warszawa: Michał Gröll, 1781.

Małecki Antoni, Juliusz Stowacki, jego życie i dzieła w stosunku do wspótczesnej epoki, t. 1, Lwów: nakł. autora, 1866.

Martuszewska Anna, Józef Ignacy Kraszewski między romansem a powieścią, [w:] Kraszewski - poeta i światy, red. Tadeusz Budrewicz, Ewa Ihnatowicz i Ewa Owczarz, Toruń: Wydawnictwo Naukowe Uniwersytetu Mikołaja Kopernika, 2012.

Pomian Krzysztof, Historia między retoryką a teologią. Niektóre problemy myśli historycznej doby Odrodzenia i reformacji, „Odrodzenie i Reformacja w Polsce” 1964, t. IX.

Prus Bolesław, rubryka Korespondencje „Kraju”, Al. G., „Kraj” 1884, nr 5.

Słowacki Euzebiusz, Prawidta wymowy i poezji wyjęte z „Dzieł”, Wilno: Józef Zawadzki, 1826.

Słowacki Juliusz, Poemat Piasta Dantyszka herbu Leliwa o piekle, Paryż 1839.

Treugutt Stefan, Fides, Spes, Caritas, „Teksty Drugie” 1992, nr 4.

Woźniakiewicz-Dziadosz Maria, Między buntem a rezygnacją. O powieściach Narcyzy Żmichowskiej, Warszawa: Państwowy Instytut Wydawniczy, 1978.

Żmichowska Narcyza, Wolne chwile Gabryelli, t. 1, Poznań: Księgarnia J. K. Żupańskiego,1845.

[-], O najnowszej powieści J. Korzeniowskiego pt. „Spekulant”, „Przegląd Naukowy” 1846, t. 3, nr 27.

[-], Usprawiedliwienie się wydawczyni „Książki pamiątek”, „Przegląd Naukowy” 1848, R. VII, nr 10 (z 10 kwietnia 1848 roku).

—, O Pawle Edmundzie Strzeleckim wedlug rodzinnych i towarzyskich wspomnień, „Ateneum” 1876, t. 1 , z. 2 i 3.

—, Pisma Narcyzy Żmichowskiej (Gabryelli) z życiorysem autorki skreślonym przez dra Piotra Chmielowskiego, oprac. P. Chmielowski, t. 2-3, Warszawa: nakł. Michała Glücksberga, 1885.

—, Książka pamiątek [rodz. I-XII], „Przegląd Naukowy” 1847, t. 1-3; 1848, t. 2; rozdziały XIII i XIV: Dalszy ciag „Książki pamiątek” N. Żmichowskiej znaleziony w papierach autorki, „Bluszcz” 1885 , nr 27-30.

—, Czy to powieść?, przedm. Tadeusza Boya-Żeleńskiego, Warszawa: Dom Książki Polskiej, 1929.

—, Narcyssa i Wanda: listy Narcyzy Żmichowskiej do Wandy Grabowskiej (Żeleńskiej), wyd. i wstęp Tadeusz Żeleński (Boy), Warszawa: Dom Książki Polskiej, 1930.

—, Listy, t. 1: W kręgu najbliższych, do dr. przygot. i koment. opatrzyła Mieczysława Romankówna, red. Stanisław Pigoń, Wrocław: Zakład Narodowy im. Ossolińskich, 1957. 
—, Listy, t. 2: Rozdroża, do dr. przygot. i koment. opatrzyła Mieczysława Romankówna, red. Stanisław Pigoń, Wrocław: Zakład Narodowy im. Ossolińskich, 1960.

—, Listy, t. 3: Miodogórze, do dr. przygot. i koment. opatrzyła Mieczysława Romankówna, red. Stanisław Pigonia, Wrocław: Zakład Narodowy im. Ossolińskich, 1967.

—, Narcyssa i Wanda, wyd. Barbara Winklowa i Helena Żytkowicz, Warszawa: Fundacja Akademia Humanistyczna-Instytut Badań Literackich PAN, 2007. 